\title{
Are sugarcane leaf-detritus well colonized by aquatic macroinvertebrates?
}

\author{
Detritos foliares de cana-de-açúcar são bem colonizados \\ por macroinvertebrados aquáticos?
}

\section{Luciene Aparecida Leite-Rossi and Susana Trivinho-Strixino}

Departamento de Hidrobiologia, Universidade Federal de São Carlos - UFSCar, Rod. Washington Luiz, Km 235, CEP 13565-905, São Carlos, SP, Brazil e-mail: luciene.rossi@yahoo.com.br; strixino@power.ufscar.br

\begin{abstract}
Aim: The aim was to compare the kinetics of decomposition and the colonization of leaf litter of two plant species, the native Talauma ovata (pinha-dobrejo) and the exotic Saccharum officinarum (sugarcane), by aquatic macroinvertebrates; Methods: From each substrate, three recipients of colonization were taken from a stream, and the specimens identified to the lowest taxonomic level on days 7, 15, 34, 44, 61 and 75. The debris was weighed at the beginning and end of the experiment and determined their cell wall fractions; Results: The coefficients of mineralization indicated higher velocity decay of organic matter refractory in T. ovata. There was no difference in taxonomic structure of macroinvertebrates, between the two substrates, but the community exhibited distinct functional feeding groups in the peak of colonization, with a greater number of shredders in T. ovata. The successive states of decomposition of the two plant detritus showed distinct macroinvertebrate densities; Conclusions: The amount and state of the plant biomass were important factors influencing the density and diversity of the macroinvertebrate fauna throughout the process of organic decomposition. forest.

Keywords: Chironomidae, shredders, Saccharum officinarum, Talauma ovata, riparian
\end{abstract}

Resumo: Objetivo: O principal objetivo foi comparar a cinética de decomposição e a colonização de detritos de duas espécies de plantas: a nativa Talauma ovata (pinhado-brejo) e a exótica Saccharum officinarum (cana-de-açúcar) por macroinvertebrados; Métodos: Para cada substrato, três recipientes de colonização foram retirados de um riacho e os espécimes identificados até o menor nível taxonômico nos dias 7, 15, 34, 44, 61 e 75 . Os detritos foram pesados no início e ao final do experimento e determinadas suas fraçôes de parede celular; Resultados: Os coeficientes de mineralizaçâo indicaram maior velocidade de decaimento da matéria orgânica refratária nos detritos de T. ovata. Os dois substratos não apresentaram diferenças na estrutura taxonômica da comunidade, mas apresentaram agrupamentos funcionais distintos no pico de colonização, com maior número de fragmentadores em T. ovata. Os diferentes estados de decomposiçáo dos dois tipos de detritos vegetais apresentaram densidades faunísticas distintas; Conclusóes: A quantidade e estado da biomassa vegetal são fatores importantes que influenciam a densidade e diversidade da fauna de macroinvertebrados durante o processo de decomposição orgânica.

Palavras-chave: Chironomidae, fragmentadores, Saccharum officinarum, Talauma ovata, vegetação ripária.

\section{Introduction}

Riparian vegetation is a transition zone between aquatic and terrestrial ecosystems (Richardson et al., 2007) and has an important role in the functioning of ecosystem processes and maintenance of the characteristics of water bodies (i.e, hydraulic channel morphology, water quality, speed and residence time of water, stream bed and limnological variables)
(Naiman and Décamps, 1997, Tabacchi et al., 2000; Francis, 2006; Richardson et al., 2007). One of the most important functions is the supply of organic matter in the form of plant detritus to the water body. In low-order streams, the plant remains are the main source of energy in the aquatic system (Trevisan and Hepp, 2007) since the primary 
production is limited by the shading vegetation itself (Abelho, 2001, Gonçalves Junior et al. 2006; Graça and Canhoto, 2006). In many cases, the leaf-detritus are the most abundant fraction of allochthonous particulate organic matter (Gonçalves Junior et al., 2006) in these systems and its decomposition is an important process to input organic carbon on the stream.

The decomposition of this leaf litter in streams is a process that depends on the attributes of the plant material and the intrinsic characteristics of the stream, each of which affects the formation of biofilm on detritus, microbial decomposition and macroinvertebrate colonization (Wright and Covich, 2005; Leroy and Marks, 2006; Trevisan and Hepp, 2007).

The stages of the decomposition of leafdetritus, the analysis of conditioning factors and participation of aquatic biota in this process have been analysed and discussed by several authors (Mason, 1980; Gessner et al., 1999; Cunha-Santino and Bianchini Junior, 2000, 2006; Abelho, 2001; Graça, 2001).

The role of aquatic macroinvertebrates is recognized for its possible association with the mechanical process of fragmentation (Wright and Covich, 2005; Gonçalves Junior et al., 2006; Wantzen and Wagner, 2006, Tanaka et al., 2006), which tends to increase the contact surface available for the action of microorganisms. However, the contribution of macroinvertebrates in tropical streams to this process is not yet fully elucidated because according to Moulton et al. (2010) the shredders are in low abundance and proportion in these systems. It is known that plant remains are potential sources of food and can serve as shelter for these fauna or there may be an interaction between these factors (Dudgeon and Wu, 1999; Graça, 2001). Therefore the presence of riparian vegetation is a very important resource for the macroinvertebrate fauna.

Freshwater systems and riparian forest are subject to degradation in different places (Tockner and Stanford, 2002). It is increasingly recognized that the rehabilitation and recovery of these systems are essential for the conservation of biodiversity and maintenance of their proper role in the ecosystem (Kyle and Leishman, 2009). However, inappropriate agricultural practices have led to the loss of native vegetation, including riparian forest, and its replacement by monocultures of economic interest (Corbi and Trivinho-Strixino, 2006) altering markedly the quality and quantity of allochthonous matter and, consequently, the communities and functional processes in lotic systems (Graça, 2001; Corbi and Trivinho-Strixino, 2008; Beltrão et al. 2009; Casatti et al. 2009; Pramual and Kuvangkadilok, 2009, Zhang et al., 2010).

The cultivation of sugarcane has expanded in Brazil in recent years, mainly in the Southeast and Northeast regions, as a result of the use of alcohol as an automotive fuel, with a view to diversifying sources of energy and consequently reducing dependence on fossil fuels (ANEEL, 2008). The consequences of replacing the native vegetation with this type of monoculture are not entirely known, but it is known that the fauna composition tends to change when changes occur in the type of vegetation (Ormerod et al., 1993).

In view of this problem, a study was conducted with the aim to compare the kinetics of decomposition and the colonization of leaf litter of two plant species, the native Talauma ovata (pinhado-brejo) and the exotic Saccharum officinarum (sugarcane), by aquatic macroinvertebrates. Talauma ovata (Magnoliaceae) is a perennial representative species of the riparian forest in the southeast region of Brazil (Antunes and Ribeiro, 1999) with leaves devoid of pile, veins reticulate, simple blade with margins entire, apex and base acute. The leaf-detritus of this plant have been used previously in colonization and decomposition experiments (Janke and Trivinho-Strixino, 2007; Gimenes et al., 2012). The monocotyledon Saccharum officinarum (Poaceae) has hairy leaves (silica spicules) with parallel veins, simple blade, ciliated margin, invaginate base and acute apex.

Differences in nutritional content, structural features and palatability of plant detritus can result in different rates of leaf breakdown and macroinvertebrate colonization. Being an exotic plant with high silica content in its leaves, it is expected that leaf-detritus from sugarcane presents lower decomposition rate than the native plant. Similarly it should be less attractive to macroinvertebrate shredders. Thus, in this study were tested the following hypothesis: 1) the rate of mass loss during decomposition is lower in S.officinarum leaf-detritus than in native plant leaf-detritus; 2) the leaf-detritus of T. ovata shelters more shredders than S. officinarum leaf-detritus; 3) the numerical macroinvertebrate density is greater when the leaf-detritus structural features is more heterogeneous. 


\section{Material and Methods}

\subsection{Experimental procedures}

The leaves of T. ovata were collected on the banks of the stream Córrego do Espraiado, São Carlos, upstate São Paulo, Brazil at the beginning of flowering, ie, in the dry season. The leaves undergoing senescence were taken directly from the adult plant. The leaves of $S$. officinarum were collected within $30 \mathrm{~km}$ of the $T$. ovata site, in a monoculture located between the towns of Araraquara and Ibaté $\left(21^{\circ} 52^{\prime} \mathrm{S}\right.$ by $\left.48^{\circ} 0.5^{\prime} \mathrm{W}\right)$, also in the dry season, when the plant was in the ripening period (just before harvest). The leaves of both species were washed in running water to remove any material that could interfere with the gravimetric method (inorganic material, small animals, animal feces) and were subsequently dried at $60{ }^{\circ} \mathrm{C}$ to constant weight and cut in fragments (average size $=8.02 \pm 3.62 \mathrm{~cm}$ ). This procedure is recommended for better assessment of the rates of colonization and to make the samples more uniform (Bärlocher, 1997).

The leaf fragments were placed in polyethylene bottles (volume $=500 \mathrm{~mL}$ ) with approximately 220 to 250 holes $(0.5 \mathrm{~cm}$ average diameter) and screw caps. These bottles minimize the drift of leaf particles fragmented during the experiment. Forty-two of these bottles, half containing $12 \mathrm{~g}$ of $T$. ovata leaf-detritus and half with the same weight of S. officinarum leaf-detritus, were deposited on the Córrego do Espraiado stream bed stretch (depth $<1 \mathrm{~m}$ ), spaced by about $0.5 \mathrm{~m}$. This is a first order stream located on coordinates $21^{\circ} 53^{\circ} \mathrm{S}$ and $47^{\circ} 52^{\prime} \mathrm{W}$ in a Cerrado area with slightly acid $\mathrm{pH}$ (average $=5.49 \pm 0.33$ ), oxygen concentration around $6.91 \pm 0.56 \mathrm{mg} \cdot \mathrm{L}^{-1}$ and, in the period of the experiment, showed a minimum temperature of $14^{\circ} \mathrm{C}$ and maximum of $20^{\circ} \mathrm{C}$. It is preserved, heterogeneous riparian vegetation, with sandy bottom substrate and low water velocity (Corbi and Trivinho-Strixino, 2008).

\subsection{Data collection}

The samples (3 bottles of each detritus) were removed after $7,15,34,44,61$ and 75 days of incubation, isolated in plastic carboys containing water from the site and transported to the laboratory for screening procedures. The fauna was sorted on illuminated trays and naked eye, still alive, after washing through a sieve (mesh $0.25 \mathrm{~mm}$ ) and fixed in $70 \%$ ethanol, except Oligochaeta and Turbellaria previously fixed in
$10 \%$ formaldehyde solution. The organisms were identified with the aid of identification keys and specialists (Trivinho-Strixino, 2011; Nieser and Melo, 1997; Domínguez et al., 2006, Domínguez and Fernández, 2004; Brinkhurst and Marchese, 1989; Lecci and Froehlich, 2007; Costa et al. 2004; Pes et al., 2005; Passos et al. 2007).

The trophic structure of the settler community was assessed by referring to the classification of feeding guilds Merritt and Cummins (1996) and Cummins et al. (2005), complemented by microscopic examination of digestive tracts of the larvae of Chironomidae. In this study were considered the following feeding groups: Collectors, Shredders, Scrapers and Predators.

The remaining plant detritus was dried at $60^{\circ} \mathrm{C}$ for 48 hours and its mass determined on analytical balance, in order to determine the organic matter mass decay. To determine the inorganic matter aggregated in plant detritus during the experiment, an aliquot of each sample was calcined for 2 hours at $550{ }^{\circ} \mathrm{C}$ (Wetzel and Likens, 1991). The cell wall fractions (CWF) of the remaining detritus were determined by a modified analytical method of Van Soest and Wine (1967) for all sampling periods.

\subsection{Data treatment}

To analyze the decay of organic matter, a first order kinetic model (Equation 1) was adjusted by the Levenberg-Marquardt algorithm (Press et al., 1993; Bianchini Junior., 2003), where the inorganic fractions obtained from calcination were subtracted from the total remaining mass. To determine the CWF, another kinetic model was fitted (Equation 2):

$\mathrm{POM}=\mathrm{POM}_{\mathrm{L}} \cdot \mathrm{e}^{-\mathrm{kt}+} \mathrm{POM}_{\mathrm{R}} \cdot \mathrm{e}^{-\mathrm{kt}}$

$\mathrm{POM}=\mathrm{POM}_{\mathrm{R}} \cdot \mathrm{e}^{-\mathrm{k}}{ }_{3}$

where, $\mathrm{POM}=$ particulate organic matter; $\mathrm{POM}_{\mathrm{L}}=$ labile particulate organic matter; $\mathrm{POM}_{\mathrm{R}}=$ refractory particulate organic matter; $\mathrm{k}_{1}=\mathrm{POM}_{\mathrm{L}}$ mineralization coefficient $\left(\mathrm{day}^{-1}\right)$, $\mathrm{k}_{2}=\mathrm{k}_{3=} \mathrm{POM}_{\mathrm{R}}$ mineralization coefficient $\left(\mathrm{day}^{-1}\right)$; $\mathrm{e}=$ vase of natural logarithms and $\mathrm{t}=$ time (days). The data were subject to the generalized linear model (GLM) to check for possible differences in weight loss and CWF (response variables) in terms of type of leaf-detritus (T. ovata and $S$. officinarum - categorical variable), sampling periods (time (days) - continuous variable) and an interaction between these two factors.

The half-life $\left(t \frac{1}{2}\right)$ was determined from the coefficient $\mathrm{k}$, according to the following Equation 3: 
$\mathrm{t} 1 / 2=\ln (0.5) /-\mathrm{k}$

To evaluate the physical feature of leaf-detritus (heterogeneity) during sampling periods were considered: 1) the change of the leaf appearance, through observation in stereoscopic microscopy and, 2) the change in proportion of CWF in relation to other components (CWF:OC) (intrinsic or non-intrinsic).

The fauna data were analyzed in number of individuals per gram of dry weight (n. indiv. $\mathrm{gdry}^{-1}$ ), relative participation, richness, diversity and functional feeding groups. The sampling periods (time) and the type of leaf-detritus always were considered continuous and categorical variables respectively and the remaining variables as response. To evaluate the influence of the sampling periods, type of leaf-detritus and the interaction between these two factors on macroinvertebrate numerical densities, were used GLM and ANOSIM analysis. To diversity was performed a GLM and evaluated the Brillouin diversity indices, which is indicate when the random of samples is not secure (Magurran, 2004). The density of each functional feeding group was evaluated using 4 GLMs (one for each functional group), considering sampling periods, type of detritus and interaction between these two factors. Furthermore, a GLM was performed in the period of the peak colonization, to each functional feeding group, to compare the two types of leaf-detritus. To evaluate the effects of the plant detritus, sampling periods and interaction between these two factors on the functional structure of the community, was used a MANOVA/Pillai Trace test (Scheiner, 2001; Gonçalves et al., 2012).

\section{Results}

\subsection{Kinetics of leaf-detritus decomposition}

According to the kinetic model adopted above, the loss of labile fraction $\left(\mathrm{POM}_{\mathrm{L}}\right)$ during the decomposition was $12.33 \pm 6.15 \%$ in $S$. officinarum and $37.20 \pm 9.68 \%$ in T. ovata and loss of refractory fraction $\left(\mathrm{POM}_{\mathrm{R}}\right)$ was $87.7 \pm 4.9 \%$ in $S$. officinarum and $62.8 \pm 8.0 \%$ in T. ovata (Figure 1). The coefficient $\mathrm{k}_{1}\left(0.5 \pm 2.0\right.$ day $\left.^{-1}\right)$ of the adjusted model for $S$. officinarum was clearly greater than for $T$. ovata $\left(0.3 \pm 0.3 \mathrm{day}^{-1}\right)$. However, the amount of $\mathrm{POM}_{\mathrm{L}}$ released by $T$. ovata was three times higher than that observed in S. officinarum decomposition. Consequently, the half-lives of these remaining materials were 1.4 and 2.2 days respectively in S. officinarum and T. ovata (Table 1). For both species, the refractory portion was released more slowly than the labile fraction. The rate of decomposition of this portion was higher in T. ovata $\left(\mathrm{k}_{2}=0.006 \mathrm{day}^{-1}, \mathrm{t}^{1 / 2} / 2=119.0\right.$ days $)$ than in S. officinarum $\left(\mathrm{K}_{2}=0.005\right.$ day $^{-1}, \mathrm{t}^{1 / 2}=133.3$ days $)$ (Table 1).

At the end of the experiment, there remained $55.8 \% \pm 4.8$ and $34.9 \pm 3.2 \%$ of the detritus of S. officinarum and T. ovata respectively. The statistical analysis showed significance differences between the two types of leaf-detritus $\left(\mathrm{F}_{1,8}=197.24 ; \mathrm{p}<0.001\right)$ and sampling periods $\left(\mathrm{F}_{1,8}=410.25 ; \mathrm{p}<0.001\right)$. However, no significance difference was founded when considered the interaction between these two factors on the biomass loss $\left(\mathrm{F}_{1,8}=0.32 ; \mathrm{p}=0.580\right)$.

$S$. officinarum showed sligth differences in their leaf-detritus appearance and the proportion CWF:OC was always high (beginning $=88: 11$; middle $=98: 2$; end $=85: 14$ ) during all decomposition process. In contrast, the leaf-detritus of $T$. ovata changed continuously its appearance and proportion CWF:OC (beginning = 64:36;

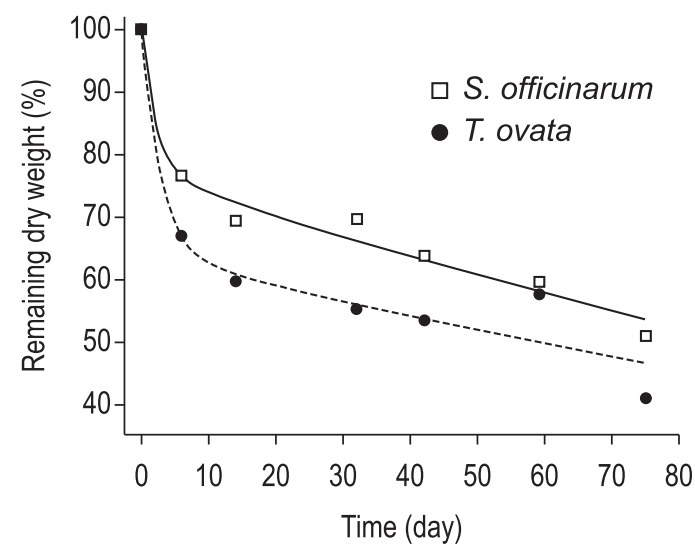

Figure 1. Decay of organic matter (\%) in S. officinarum and $T$. ovata leaf-detritus during the colonization experiment.

Table 1. Parameters of the decay kinetic models used for T. ovata and S. officinarum. Where, $\mathrm{POM}_{\mathrm{L}}=$ labile/soluble particulate organic matter; $\mathrm{POM}_{\mathrm{R}}=$ refractory particulate organic matter; $\mathrm{k}_{1}=$ mineralization coefficient for $\mathrm{POM}_{\mathrm{L}}$; $\mathrm{k}_{2}=\mathrm{POM}_{\mathrm{R}}$ mineralization coefficient; $\mathrm{t}_{1 / 2(\mathrm{k} 1-\mathrm{k} 2)}=$ half-life related to $\mathrm{k}_{1}$ and $\mathrm{k}_{2}$.

\begin{tabular}{lcc}
\hline \multicolumn{1}{c}{ Parameter } & T. ovata & S. officinarum \\
\hline $\operatorname{POM}_{\mathrm{L}}(\%)$ & $37.2 \pm 9.7$ & $12.3 \pm 6.2$ \\
$\operatorname{POM}_{\mathrm{R}}(\%)$ & $62.8 \pm 8.0$ & $87.7 \pm 4.9$ \\
$\mathrm{k}_{1}\left(\right.$ day $\left.^{-1}\right)$ & $0.3 \pm 0.3$ & $0.5 \pm 2.0$ \\
$\mathrm{k}_{2}\left(\right.$ day $\left.^{-1}\right)$ & $0.006 \pm 0.002$ & $0.005 \pm 0.001$ \\
$\mathrm{r}^{2}$ & 0.98 & 0.98 \\
$\mathrm{t}_{1 / 2(\mathrm{k} 1)(\text { day) }}$ & 2.2 & 1.4 \\
$\mathrm{t}_{1 / 2(\mathrm{k} 2)(\text { day })}$ & 119.0 & 133.3 \\
\hline
\end{tabular}


middle $=79: 21 ;$ end $=84: 16)$ until the end of the process (Figure 2). A significance difference between the two types of detritus was showed by the statistical test $\left(\mathrm{F}_{1,10}=17.10 ; \mathrm{p}=0.002\right)$.

\subsection{Fauna associated with detritus}

Overall, 3,395 specimens of macroinvertebrates from 66 taxa were analysed (Table 2). The most prevalent were the chironomids Endotribelos, Caladomyia, Tanytarsus, Ablabesmyia (Figure 3) and the mayfly Miroculis, each contributing more than $5 \%$ of the total. All the other taxa were in low abundance. Particularly, notable was the massive contribution of Endotribelos larvae on T. ovata detritus, with $22 \%$ of the total fauna, while on S. officinarum these contributed only $4 \%$; thus, the relative abundance of the Endotribelos on T. ovata detritus was almost six times higher than on S. officinarum.

During experiment it was observed that the maximum numerical density of macroinvertebrates occurred on the native plant detritus in the intermediate period (34 and 44 days of colonization - Figure 4a), showing densities 2.3 and 2.7 times higher than in leaf-detritus of $S$. officinarum. In this period, the detritus of S. officinarum showed average numerical densities
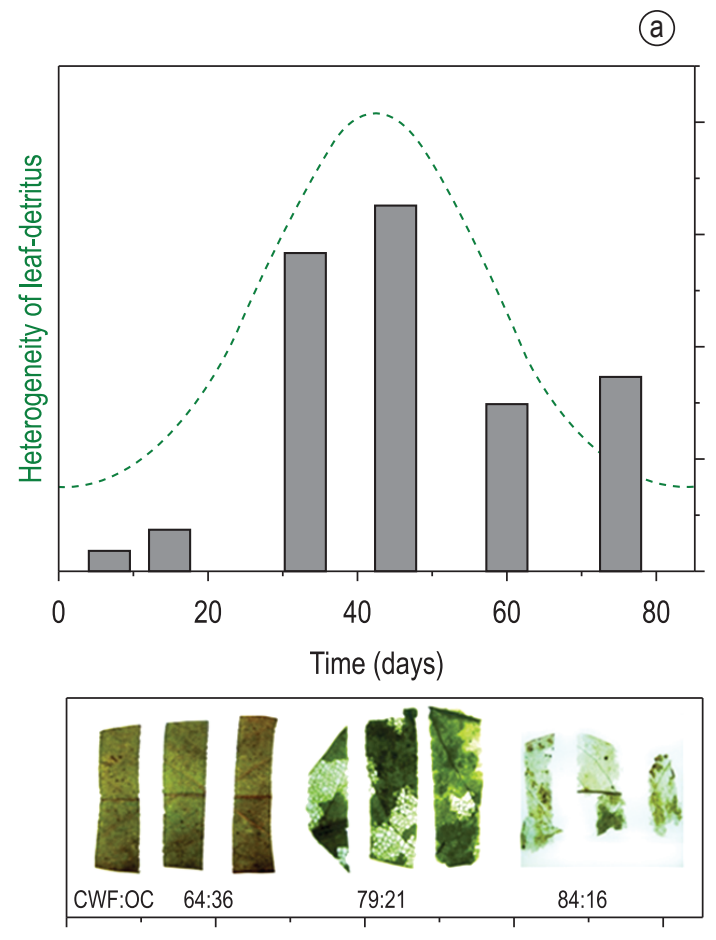

0

20 of 14.3 indiv. $g$ dry $\mathrm{w}^{-1}$ (Figure $4 \mathrm{~b}$ ). For the taxonomic structure of community, the statistical analysis indicated significance difference only to the time of colonization $\left(\mathrm{F}_{1,8}=178.31 ; \mathrm{p}=0.005\right)$. The similarity this analysis showed no significance difference $(\mathrm{R}=0.009 ; \mathrm{p}=0.360)$ between the two types of leaf-detritus. The community diversity ranged with the types of detritus $\left(\mathrm{F}_{1,8}=6.53\right.$; $\mathrm{p}=0.003)$ and with the interaction between the time of colonization and the type of leaf-detritus $\left(\mathrm{F}_{1,8}=45.116 ; \mathrm{p}<0.001\right)$, being the macrofauna more diverse in $S$. officinarum then T. ovata.

Overall, T. ovata was colonized by: $48.6 \%$ collectors; $30.8 \%$ shredders, $19.1 \%$ predators and $0.2 \%$ scrapers (Figure 5a). S. officinarum detritus were colonized by $61.1 \%$ collectors, $10.3 \%$ shredders, $26.8 \%$ predators and $1.81 \%$ scrapers (Figure $5 \mathrm{~b}$ ). The numerical density of functional feeding groups was not different $\left(\mathrm{F}_{4,5}=0.51\right.$; $\mathrm{p}=0.720)$ when analyzed the effect of the types of leaf-detritus on all macroinvertebrate community, but there was significance difference when considered the time of decomposition $\left(\mathrm{F}_{4,5}=33.46 ; \mathrm{p}<0.001\right)$. This was mainly by differential participation of the collector $\left(\mathrm{F}_{1,8}=7.72 ; \mathrm{p}=0.02\right)$ and predator groups $\left(\mathrm{F}_{1,8}=26.89 ; \mathrm{p}<0.001\right)$. In contrast the analysis considering only the functional feeding

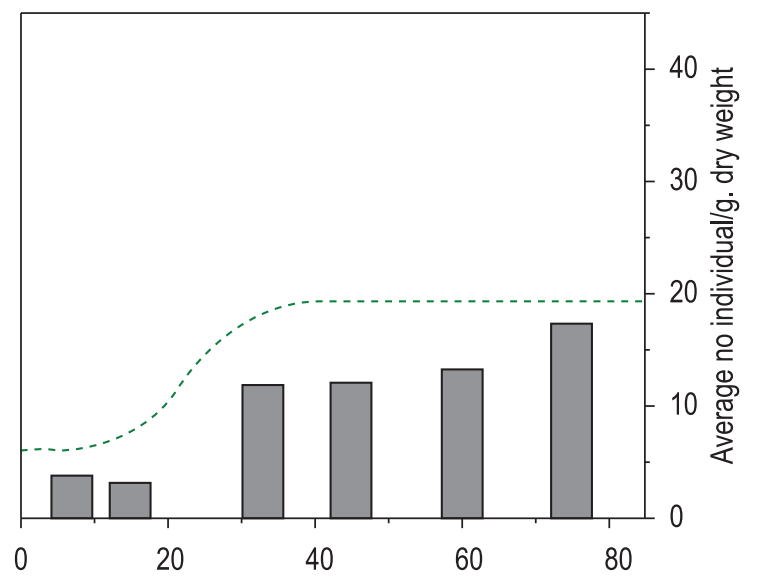

Time (days)
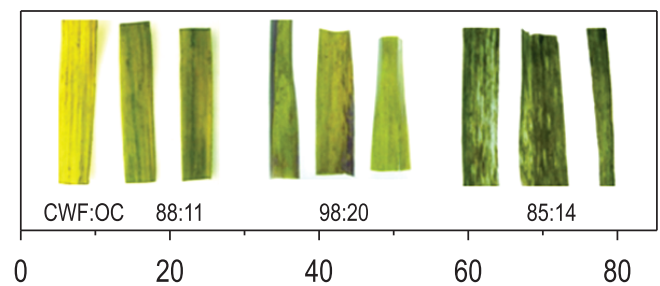

20

40

60

80

Figure 2. Density of the macroinvertebrates (columns) and hypothetical curve of heterogeneity of leaf-detritus (dotted line) in T. ovata (a) and S. officinarum (b) during the experiment, demonstrating the cyclic model of invasion and exclusion of Armesto et al. (1991). 
Table 2. List of taxa and numbers of individuals observed in detritus of T. ovata and S. officinarum. The bold numbers represents the taxa representing $>10 \%$ of total fauna.

\begin{tabular}{|c|c|c|c|c|c|}
\hline Taxa & T. ovata & S. officinarum & Taxa & T. ovata & S. officinarum \\
\hline Plecoptera & & & Chironomidae & & \\
\hline Tupiperla & 3 & 2 & Ablabesmyia & 125 & 141 \\
\hline Anacroneuria & 3 & 3 & Beardius & 2 & - \\
\hline Kempnyia & 8 & 4 & Caladomyia & 118 & 145 \\
\hline Ephemeroptera & & & Chironomus & 22 & 18 \\
\hline Guajirolus & 6 & 13 & Constempellina & - & 1 \\
\hline Massartela & 1 & - & Corynoneura & 21 & 34 \\
\hline Askola & 25 & 56 & Endotribelos & 408 & 52 \\
\hline Hagenulopsis & 39 & 31 & Fissimentum & 1 & - \\
\hline Miroculis & 94 & 104 & Fittkauimyia & 2 & 2 \\
\hline Leptophlebiidae & 3 & 1 & Labrundinia & 12 & 9 \\
\hline Hemiptera & & & Larsia & - & 1 \\
\hline Neoplea & 75 & 56 & Lopescladius & 8 & 6 \\
\hline Paraplea & 46 & 33 & Nanocladius & 11 & 5 \\
\hline Odonata & & & Oukuriella & 3 & - \\
\hline Limnocoris & 1 & 4 & Parametriocnemus & 7 & - \\
\hline Argia & 3 & 1 & Pentaneura & 37 & 58 \\
\hline Trichoptera & & & Phaenopsectra & 31 & 14 \\
\hline Atanatolia & - & 2 & Polypedilum & 93 & 23 \\
\hline Cyrnellus & 1 & - & Rheotanytarsus & 6 & 7 \\
\hline Macronema & 5 & 10 & Stempellina & - & 2 \\
\hline Marilia & 14 & 25 & Stempellinella & 51 & 36 \\
\hline Neotrichia & 1 & 1 & Stenochironomus & 1 & 4 \\
\hline Oecetis & - & 3 & Tanytarsini no det. & 117 & 95 \\
\hline Phylloicus & 4 & 3 & Tanytarsus & 307 & 139 \\
\hline Smicridea & 10 & 5 & & & \\
\hline Triplectides egleri & 14 & 9 & Hydracarina & 2 & 4 \\
\hline \multicolumn{6}{|l|}{ Coleoptera } \\
\hline Elmidae & 1 & - & Annelida & & \\
\hline Heterelmis(larvae) & 1 & 1 & Helobdella & 1 & 13 \\
\hline Heterelmis(adults) & - & 17 & Brinkhustia americanus & 4 & 6 \\
\hline Hexacylloepus (larvae) & - & 1 & Allonais paraguayensis & 49 & 56 \\
\hline Hexacylloepus (adults) & 3 & 4 & Slavina & - & 1 \\
\hline Xenelmis (larvae) & - & 1 & Bothrioneurum americanus & 2 & 2 \\
\hline Gyretes & 2 & 6 & Nais comunis & - & 1 \\
\hline Diptera & & & imature Tubificidae & 1 & 2 \\
\hline Ceratopogonidae & 12 & 10 & & & \\
\hline Empididae & 1 & - & Turbellaria & & \\
\hline Tabanidae & 1 & - & Girardia tigrina & 38 & 51 \\
\hline Tipulidae & 2 & - & & & \\
\hline Total & 379 & 406 & Total & 1480 & 928 \\
\hline
\end{tabular}

groups on the peak of colonization (34-45 days) showed significance difference between the two types of plants detritus in three groups: collectors $\left(F_{1,3}=51.92 ; \mathrm{p}=0.001\right)$, shredders $\left(\mathrm{F}_{1,3}=473.38\right.$; $\mathrm{p}=0.002)$ and predators $\left(\mathrm{F}_{1,3}=95.68 ; \mathrm{p}=0.001\right)$, with higher densities in T. ovata than S. officinarum.

\section{Discussion}

In general, the kinetic of decomposition is discussed in terms of the amount of biomass lost, velocity decay ( $\mathrm{k}$ coefficients) and half-life times of the labile and refractory portion of the leaf-detritus (Bianchini Junior, 1999). The differences in decay rates of plant mass, whether $\mathrm{POM}_{\mathrm{L}}$ or $\mathrm{POM}_{\mathrm{R}}$, observed in the experiment with two types of plant detritus can be attributed to factors, like chemical composition of structural parts (e.g. cellulose and lignin) differences between the two species and their nutrient content (see in Mun et al., 2001). The mass loss in the first days of decomposition $\left(\mathrm{POM}_{\mathrm{L}}\right)$ is, according to Davis III et al. (2003), due to the 
leaching process and corresponds to organic and inorganic compounds present in the protoplasm and soluble fractions of the detritus. Although the

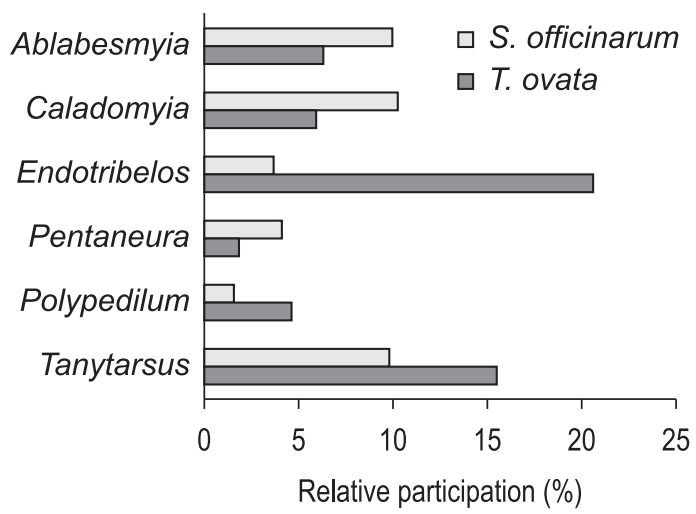

Figure 3. Relative participation of the most representative Chironomidae taxa on leaf-detritus of $T$. ovata and $S$. officinarum. leaf-detritus of T. ovata releases a major portion of this labile material, the velocity of degradation was slower than S. officinarum, probably because of the larger amounts of energy compounds (mono and polysaccharides) on sugarcane, which are essential for microbial metabolism (Gimenes et al., 2012).

The fraction $\mathrm{POM}_{\mathrm{R}}$ has a higher proportion of poorly degradable material, such as lignin, cellulose and hemicellulose, explaining its slow decomposition. This trend towards a lower rate of decomposition after the first days was observed in various studies (Bianchini Junior, 1999). The larger proportion of macroinvertebrates shredders in the peak of colonization in the leaf-detritus of $T$. ovata and its apparent tearability of the detritus must have tended to accelerate the mechanical fragmentation (Clapcott and Bunn, 2003, Gessner et al., 1999). These two factors possibly influenced in the

(a)

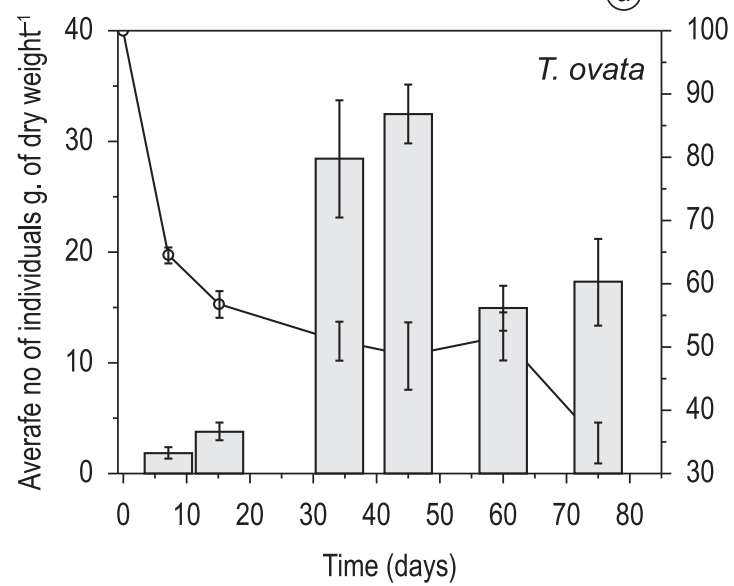

(b)

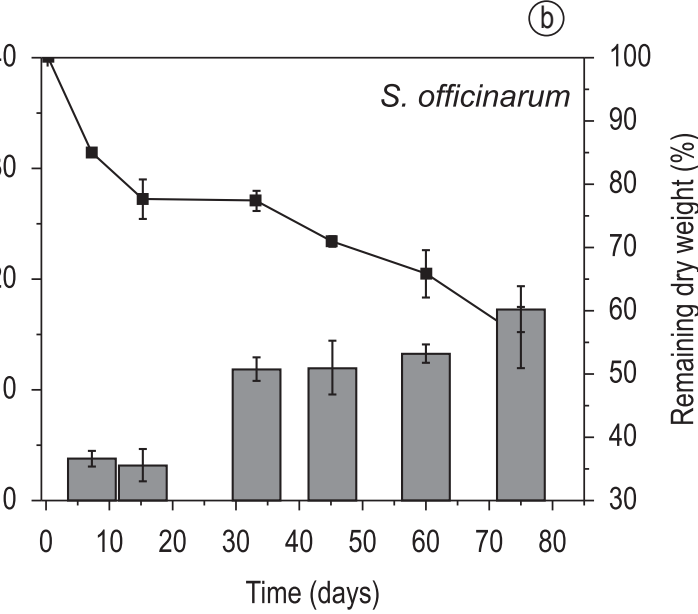

Figure 4. Mean macroinvertebrate density (ind.g dry weight ${ }^{-1}$ ) (columns) and $\%$ of remaining dry weight (solid lines) during the experiment.

T. ovata

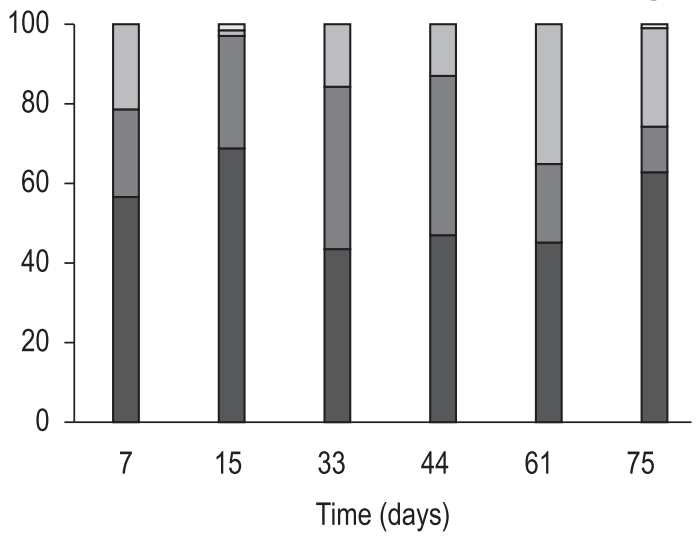

(a)

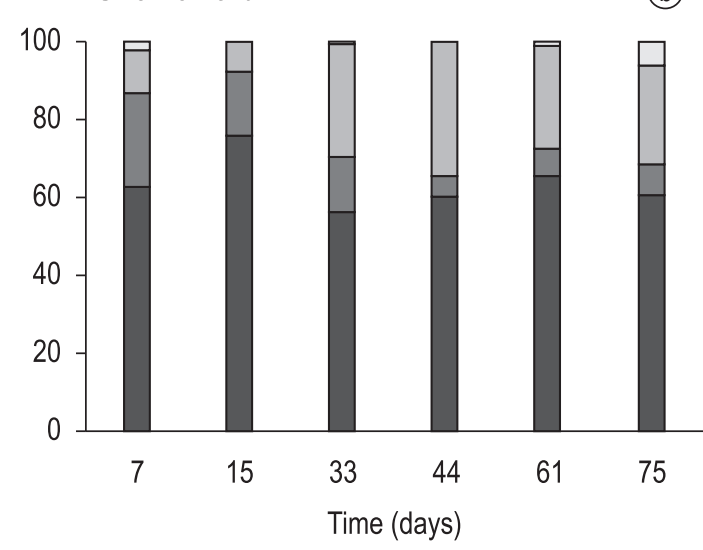

$\square$ Scrapers $\square$ Predators $\square$ Shredders $\square$ Collectors

Figure 5. Relative participation (\%) of macroinvertebrate functional feeding group during colonization. 
greater velocity of decay of the refractory material in T. ovata leaf-detritus, relative to $S$. officinarum. According to Petersen (1984), leaf-detritus that decompose faster support higher densities of settlers, as observed in T. ovata. Gimenes et al. (2012) in a decomposition experiment in vitro (ie, without macroinvertebrates or stream action) with the same plant species observed that $T$. ovata leafdetritus had a concentration of CWF 20\% higher than that found in the present study. In addition, in the same experiment, the portion of the $\mathrm{POM}_{R}$ in T. ovata leaf-detritus decomposed more slowly than in S. officinarum $\left(\mathrm{K} 2=\mathrm{K} 4=0.005 \mathrm{day}^{-1}\right.$ and $\mathrm{K} 2=\mathrm{K} 4=0.007 \mathrm{day}^{-1}$, respectively), contradicting the present result. These results seem to indicate the influence of the fauna accelerating the fragmentation of the leaf-detritus of T. ovata in the field experiment, fact not observed in S. officinarum.

The dynamics of macrofauna colonization on the plant detritus seems to follow the cyclic model of invasion and exclusion of Armesto et al. (1991), which shows alternating periods of high and low spatial heterogeneity during decomposition, the highest diversity and density occurring in periods of greater heterogeneity of the substrate. As the detritus of S. officinarum showed no obvious changes during the experiment, colonization remained almost constant, in contrast to $T$. ovata, on which the maximum density of macroinvertebrates occurred when there was greatest heterogeneity of the detritus. The schematic diagram in Figure 2 illustrates the steps in the process of colonization on the two detritus: at the beginning of experiment, both plant detritus had low densities of macroinvertebrates and there was a marked homogeneity of the leaf substrates, due to the still little action of decomposing mechanisms. Next, the density increased and the substrate had already become more heterogeneous (evident in Figure 2a), due to microbial and macroinvertebrate action. In the last days of the experiment, the substrate T. ovata returned to a more homogeneous appearance, reflecting the size and state of the particles at a late stage of decomposition. As seen in Figure 2b, the appearance of the leaf-detritus of S. officinarum did not seem to change much during the experiment, indicating low heterogeneity, and this was accompanied by a similar colonization throughout. Capello et al. (2004) reported similar observations in his study of the decomposition of leaf-detritus of Salix humboldtiana. Similarly, Gonçalves et al. (2012) attributed the changes of the physical state of detritus and faunal composition to the natural degradative succession process: a sequence of changes in colonization by organisms, which modifies the properties of the surface and improves the habitat for subsequent colonists (Gonçalves et al., 2004; Ligeiro et al., 2010).

The results of this study indicate, in general, that the state of decomposition of plant detritus and the amount of biomass present at each moment (time of colonization) were more important to the macroinvertebrate density than the type of plant detritus. Collectors, like Caladomyia, Stempellina, Tanytarsus, Allonais and Triplectides, which high participation on the detritus native plant, may not have been active in the process of decay of the organic matter in the leaf-detritus, but possibly used fine particulate organic matter as food source or the detritus provides place of refuge or settlement (Capello et al. 2004; Mathuriau and Chauvet, 2002). The colonization of the leaf-detritus of T. ovata by great numbers of larvae of Endotribelos, a chironomid larva with several shredder species (Roque et al., 2005) may have played an important part in the decomposition of the native plant. Similar results were observed by Clapcott and Bunn (2003) in Australia, in the colonization of plant detritus of Saccharum, Urochloa and Eucalyptus (native) where the action of shredders (in this case, the trichopteran Anisocentropus kirramus) was greater on native vegetation.

According to Ormerod et al. (1993), changes in the riparian vegetation appear to affect directly the composition of the benthic macroinvertebrate community. In the present study, what could be observed was the different proportion of functional groups in the two types of detritus in the peak of colonization, but not distinct taxonomic communities. Studies to be conducted in streams impacted by the monoculture of sugarcane may yet show whether there are major changes in these communities.

\section{Conclusion}

Regarding the hypotheses made at the outset, it can be concluded: (1) the rate of mass loss during decomposition was lower in S. officinarum detritus than in T. ovata; (2) T. ovata presented more shredder macroinvertebrates than S. officinarum; (3) When the leaf-detritus were more heterogeneous there were greater macroinvertebrate densities. In addition, the amount and state of the biomass were important factors influencing the density and diversity of the macroinvertebrate fauna throughout the process of organic decomposition. 


\section{Acknowledgements}

The authors thank the Foundation for Research Aid of São Paulo (FAPESP) for the scholarship and funding of this work (File: 2009/50690-8) and the Laboratório de Bioensaios e Modelagem Matemática, especially Marcela Bianchessi da Cunha Santino and Karen Zauner Gimenes, for essential comments on this manuscript.

\section{References}

ABELHO, M. 2001. From litterfall to breakdown in streams: a review. The Scientific World, vol. 1, p. 656-680. PMid:12805769. http://dx.doi. org/10.1100/tsw.2001.103

Agência Nacional de Energia Elétrica - ANEEL. 2008. Atlas de Energia Elétrica do Brasil: Biomassa. 3. ed. Brasília: Aneel. 236 p.

ANTUNES, NB. and RIBEIRO, JF. 1999. Aspectos fenológicos de seis espécies vegetais em matas de galeria do distrito federal. Pesquisa Agropecuária Brasileira, vol. 34, no. 9, p. 1517-1527.

ARMESTO, JJ., PICKET, STA. and McDONNELL, MJ. 1991. Spatial heterogeneity during succession: a cyclic model of invasion and exclusion. In KOLASA, J. and PICKETT, STA., eds. Ecological heterogeneity. New York: Springer. p. 256-269.

BÄRLOCHER, F. 1997. Pitfalls of traditional techniques when studying decomposition of vascular plant remains in aquatic habitats. Limnetica, vol. 13, no. 2, p. 1-11.

BELTRÃO, GBM., MEDEIROS, ESF. and RAMOS, RTC. 2009. Effects of riparian vegetation on the structure of the marginal aquatic habitat and the associated fish assemblage in a tropical Brazilian reservoir. Biota Neotropica, vol. 9, no. 4, p. 37-43. http://dx.doi.org/10.1590/S167606032009000400003

BIANCHINI JUNIOR, I. 1999. Aspectos do processo de decomposição nos ecossistemas aquáticos continentais. In POMPÊO, MLM., org. Perspectivas da Limnologia no Brasil. São Luis: Gráfica e Editora Uniāo. p. 21-43.

BIANCHINI JUNIOR, I. 2003. Modelos de crescimento e decomposição de macrófitas aquáticas. In THOMAZ, SM. and BINI, LM., eds. Ecologia e manejo de macrófitas aquáticas. Maringá: EDUEM. p. 85-126.

BRINKHURST, RO. and MARCHESE, MR. 1989. Guía para la identificación de Oligoquetos acuáticos continentals de sud y Centroamérica. Argentina: Associación Ciencias Naturales Del Litoral. 207 p. Coleçâo Climax, no. 5.

CAPELLO, S., MARCHESE, M. and EZCURRA DE DRAGO, I. 2004. Descomposición y colonización por invertebrados de hojas de Salix humboldtiana em la llanura aluvial del rio Paraná Medio. Amazoniana, vol. 18, no. 1-2, p. 125-143.

CASATTI, L., FERREIRA, CP. and CARVALHO, FR. 2009. Grass-dominated stream sites exhibit low fish species diversity and dominance by guppies: an assessment of two tropical pasture river basins. Hydrobiologia, vol. 632, p. 273-283. http://dx.doi. org/10.1007/s10750-009-9849-y

CLAPCOTT, JE. and BUNN, SE. 2003. Can $\mathrm{C}_{4}$ plants contribute to aquatic food webs of subtropical streams? Freshwater Biology, vol. 48, p. 1105-1116. http:// dx.doi.org/10.1046/j.1365-2427.2003.01077.x

CORBI, JJ. and TRIVINHO-STRIXINO, S. 2006. Influence of taxonomic resolution of stream macroinvertebrate communities on the evaluation of different land uses. Acta Limnologica Brasiliensia, vol. 18 , no. 4, p. 469-475.

CORBI, JJ. and TRIVINHO-STRIXINO, S. 2008. Relationship between sugar cane cultivation and stream macroinvertebrate communities. Brazilian Archives of Biology and Technology, vol. 51 no. 4, p. 769-779.

COSTA, J., SOUZA, LOI. and OLDRINI, BB. 2004. Chave para Identificação das famílias e gêneros das larvas conhecidas de Odonata do Brasil: comentários e registros bibliográficos (Insecta, Odonata). Publicaçóes Avulsas do Museu Nacional, no. 99, p. 3-42.

CUMMINS, KW., MERRITT, RW. and ANDRADE, PCN. 2005. The use of invertebrate functional groups to characterize ecosystem attributes in select streams and rivers in south Brazil. Studies on Neotropical Fauna and Environment, vol. 40, no. 1, p. 68-89.

CUNHA-SANTINO, MB. and BIANCHINI JUNIOR, I. 2000. Decomposição aeróbia e anaeróbia de Salvinia auriculata da lagoa do Infernão. In SANTOS, JE. and PIRES, JSR., eds. Estudos Integrados em Ecossistemas: Estação Ecológica de Jatai. São Carlos: RiMa. vol. 2, p. 631-643.

CUNHA-SANTINO, MB. and BIANCHINI JUNIOR, I. 2006. Modelos matemáticos aplicados aos estudos de decomposição de macrófitas aquáticas. Oecologia Brasiliensis, vol. 10, no. 2, p. 154-164. http://dx.doi. org/10.4257/oeco.2006.1002.03

DAVIS III, SE., CORRONADO-MOLINA, C., CHILDERS, DL. and DAY JUNIOR, JW. 2003. Temporally dependent $\mathrm{C}, \mathrm{N}$, and $\mathrm{P}$ dynamics associated with the decay of Rhizophora mangle $\mathrm{L}$. leaf litter in oligotrophic mangrove wetlands of the Southern Everglades. Aquatic Botany, vol. 75, p. 199-215. http://dx.doi.org/10.1016/S03043770(02)00176-6

DOMÍNGUEZ, E. and FERNÁNDEZ, HR. 2004. Guía para la determinación de los artrópodos bentônicos sudamericanos. Argentina: Universidad Nacional de 
Tucumán, Facultad de Ciencias Naturales e Instituto M. Lillo. 282 p.

DOMÍNGUEZ, E., MOLINERI, C., PESCADOR, ML., HUBBARD, MD. and NIETO, C. 2006. Ephemeroptera of South America. In: ADIS, JR., RUEDA-DELGADO, G. and WANTZEN, KM., eds. Aquatic Biodiversity in Latin America (ABLA). Sofia-Moscow: Pensoft. vol. 2, 646 p.

DUDGEON, D. and WU, KKY. 1999. Leaf litter in a tropical stream: food or substrate for macroinvertebrates? Archiv für Hydrobiologie, vol. 146, p. 65-82.

FRANCIS, RA. 2006. Allogenic and autogenic influences upon riparian vegetation dynamics. Area, vol. 38, no. 4, p. 453-464. http://dx.doi.org/10.1111/j.14754762.2006.00706.x

GESSNER, MO., CHAUVET, E. and DOBSON, M. 1999. A perspective on leaf litter breakdown in streams. Oikos, vol. 85, no. 2, p. 377-384. http:// dx.doi.org/10.2307/3546505

GIMENES, KZ., LEITE-ROSSI, LA., CUNHASANTINO, MB., BIANCHINI JUNIOR, I. and TRIVINHO-STRIXINO, S. 2012. Kinetics of the aerobic decomposition of Talauma ovata and Saccharum officinarum. Acta Scientiarum, vol. 34, no. 4, p. 419-428.

GONÇALVES, JF., SANTOS, AM. and ESTEVES, FA. 2004. The influence of the chemical composition of Typha dominguensis and Nymphaea ampla detritus on invertebrate colonization during decomposition in a Brazilian coastal lagoon. Hydrobiologia, vol. 527, p. 125-137. http://dx.doi. org/10.1023/B:HYDR.0000043190.49651.dc

GONÇALVES JUNIOR, JF., GRAÇA, MAS. and CALLISTO, M., 2006. Leaf-litter breakdown in 3 streams in temperate, Mediterranean, and Tropical Cerrado Climates. Journal of the North American Benthological Society, vol. 25, no. 2, p. 344-355. http:// dx.doi.org/10.1899/0887-3593(2006)25[344:LBIS IT]2.0.CO;2

GONÇALVES, JF., REZENDE, RS., FRANÇA, J. and CALLISTO, M. 2012. Invertebrate colonization during leaf processing of native, exotic and artificial detritos in a tropical stream. Marine and Freshwater Research, vol. 63, p. 428-439. http://dx.doi. org/10.1071/MF11172

GRAÇA, M. 2001. The role of invertebrates on leaf litter decomposition in streams - a review. International Review of Hydrobiology, vol. 86, no. 4-5, p. 383-393. http://dx.doi. org/10.1002/1522-2632(200107)86:4/5<383::AIDIROH383>3.0.CO;2-D

GRAÇA, MAS. and CANHOTO, C. 2006. Leaf litter processing in low order streams. Limnetica, vol. 25, no. 1-2, p. 1-10.
JANKE, H. and TRIVINHO-STRIXINO, S. 2007. Colonization of leaf litter by aquatic macroinvertebrates: a study in a low order tropical stream. Acta Limnologica Brasiliensia, vol. 19, no.1, p. 109-115.

KYLE, G. and LEISHMAN, MR. 2009. Functional trait differences between extant exotic, native and extinct native plants in the Hunter River, NSW: a potential tool in riparian rehabilitation. River Research and Applications, vol. 25, p. 892-903. http://dx.doi. org/10.1002/rra.1192

LECCI, LS. and FROEHLICH, CG. 2007. Plecoptera. In FROEHLICH, CG., org. Guia online: Identificação de larvas de insetos aquáticos do Estado de São Paulo. Available from: <http://sites.ffclrp.usp.br/aguadoce/ guiaonline>.

LEROY, CJ. and MARKS, JC. 2006. Litter quality, stream characteristics and litter diversity influence decomposition rates and macroinvertebrates. Freshwater Biology, vol. 51, p. 605-617. http://dx.doi. org/10.1111/j.1365-2427.2006.01512.x

LIGEIRO, R., MORETTI, MS., GONÇALVES JUNIOR, JF. and CALLISTO, M. 2010. What is more important for invertebrate colonization in a stream with low quality litter inputs: exposure time or leaf species? Hydrobiologia, vol. 654, p. 125-136. http://dx.doi.org/10.1007/s10750-010-0375-8

MAGURRAN, AE. 2004. Measuring Biological Diversity. 2nd. Blackwell: Oxford.

MASON, CF. 1980. Decomposição. São Paulo: Editora Pedagógica e Universitária; Editora da Universidade de São Paulo. 63 p.

MATHURIAU, C. and CHAUVET, E. 2002. Breakdown of leaf litter a Neotropical stream. Journal of the North American Benthological Society, vol. 21, no. 3, p. 384-396. http://dx.doi.org/10.2307/1468477

MERRITT, RW. and CUMMINS, KW. 1996. An introduction to the aquatic insects of North America. Dubuque: Kendall, Hunt. 862 p.

MOULTON, TP., MAGALHÁES-FRAGA, SAP., BRITO, EF. and BARBOSA, FA. 2010. Macroconsumers are more important than specialist macroinvertebrate shredders in leaf processing in urban forest streams of Rio de Janeiro, Brazil. Hydrobiologia, vol. 638, p. 55-66. http://dx.doi. org/10.1007/s10750-009-0009-1

MUN, HT., NAMGUNG, J. and KIM, JH. 2001. Decay rate and changes of nutrients during decomposition of Zizania latifolia. Korean Journal of Ecology, vol. 24, no. 2, p. 81-85.

NAIMAN, RJ. and DÉCAMPS, H. 1997. The ecology of interfaces: riparian zones. Annual Review of Ecology and Systematics, vol. 28, p. 621-658. http://dx.doi. org/10.1146/annurev.ecolsys.28.1.621

NIESER, N. and MELO, AL. 1997. Os heterópteros aquáticos de Minas Gerais: Guia introdutório com 
chave de identificação para as Espécies de Neomorpha e Gerromorpha. Minas Gerais: UFMG. 180 p.

ORMEROD, SJ., RUNDLE, SD., LLOYD, EC. and DOUGLAS, AA. 1993. The influence of riparian management on the habitat structure and macroinvertebrate communities of upland streams draining plantation forests. Journal of Applied Ecology, vol. 30, p. 13-24. http://dx.doi. org/10.2307/2404266

PASSOS, MIS., NESSIMIAN, JL. and FERREIRA JUNIOR, N. 2007. Chaves para identificação dos gêneros de Elmidae (Coleoptera) ocorrentes no Estado do Rio de Janeiro, Brasil. Revista Brasileira de Entomologia, vol. 51, no. 1, p. 42-53.

PES, AMO., HAMADA, N. and NESSIMIAN, JL. 2005. Chaves de Identificação de larvas para famílias e gêneros de Trichoptera (Insecta) da Amazônia Central, Brasil. Revista Brasileira de Entomologia, vol. 49, no. 2, p. 181-204. http://dx.doi. org/10.1590/S0085-56262005000200002

PETERSEN, RC. 1984. Detritus decomposition in endogenous and exogenous rivers of a tropical wetland. Verhandlungen des Internationalen Verein Limnologie, vol. 22, p. 1926-1931.

PRAMUAL, P. and KUVANGKADILOK, C. 2009. Agricultural land use and black fly (Diptera, Simuliidae) species richness and species assemblages in tropical streams, Northeastern Thailand. Hydrobiologia, vol. 625, p. 173-184. http://dx.doi. org/10.1007/s10750-009-9706-z

PRESS, WH., TEUKOLSKY, SA., VETTERLING, WT. and FLANNERY, BP. 1993. Numerical recipes in C: the art of scientific computing. New York: Cambridge University Press. 994 p.

RICHARDSON, DM., HOLMES PM., ESLER, KJ., GALATOWITSCH, SM., STROMBERG, JC., KIRKMAN, SP., PYSEK, P. and HOBBS, R. 2007. Riparian vegetation: degradation, alien plant invasion, and restoration prospects. Diversity and Distributions, vol. 13, p. 126-139. http://dx.doi. org/10.1111/j.1366-9516.2006.00314.x

ROQUE, FO., SIQUEIRA, T. and TRIVINHOSTRIXINO, S. 2005. Occurrence of chironomid larvae living inside fallen-fruits in Atlantic Forest streams, Brasil. Entomologia y Vectores, vol. 12, no. 2, p. 275-282. http://dx.doi.org/10.1590/S032803812005000200011

SCHEINER, SM. 2001. Multiple response variables and multispecies interactions. In SCHEINER, SM. and GUREVITCH, J., eds. Design and Analysis of
Ecological Experiments. New York: Oxford University Press. p. 94-112.

TABACCHI, E., LAMBS, L., GUILLOY, H., PLANTYTABACCHI, AM., MULLER, E. and DÉCAMPS, H. 2000. Impacts of riparian vegetation on hydrological processes. Hydrological Processes, vol. 14, p. 2959-2976. http://dx.doi.org/10.1002/10991085(200011/12)14:16/17<2959::AIDHYP129>3.0.CO;2-B

TANAKA, MO., RIBAS, ACA. and SOUZA, ALT. 2006. Macroinvertebrate succession during leaf litter breakdown in a perennial karstic river in Western Brazil. Hydrobiologia, vol. 568, no. 1, p. 493-498. http://dx.doi.org/10.1007/s10750-006-0195-z

TOCKNER, K. and STANFORD, JA. 2002. Riverine flood plains: present state and future trends. Environmental Conservation, vol. 29, no. 3, p. 308-330. http://dx.doi.org/10.1017/S037689290200022X

TREVISAN, A. and HEPP, LU. 2007. Dinâmica de componentes químicos vegetais e fauna associada ao processo de decomposição de espécies arbóreas em um riacho do norte do Rio Grande do Sul, Brasil. Neotropical Biology and Conservation, vol. 2, no. 1, p. 55-60.

TRIVINHO-STRIXINO, S. 2011. Larvas de Chironomidae: Guia de identificação. São Carlos: gráfica UFScar. vols. 1, 2 e 3, 371 p.

VAN SOEST, PJ. and WINE, RH. 1967. Use of detergents in the analysis of fibrous feeds IV. Determination of plant cell wall constituents. Journal of Association of Official Analytical Chemists, vol. 56, p. $50-55$.

WANTZEN, KM. and WAGNER, R. 2006. Detritus processing by invertebrate shredders: a neotropicaltemperate comparison. Journal of the North American Benthological Society, vol. 25, no. 1, p. 214-230.

WETZEL, RG. and LIKENS, GE. 1991. Limnological analysis. 2nd ed. New York: W. B. Saunders Company. $391 \mathrm{p}$.

WRIGHT, MS. and COVICH, AP. 2005. The effect of macroinvertebrate exclusion on leaf breakdown rates in a tropical headwater stream. Biotropica, vol. 37, no. 3, p. 403-408. http://dx.doi.org/10.1111/j.17447429.2005.00053.x

ZHANG, Y., DUDGEON, D., CHENG, D., THOE, W., FOK, L., WANG, Z. and LEE, JHW. 2010. Impacts of land use and water quality on macroinvertebrate communities in the Pearl River drainage basin, China. Hydrobiologia, vol. 652, no. 1, p. 71-88. http://dx.doi.org/10.1007/s10750010-0320-x 